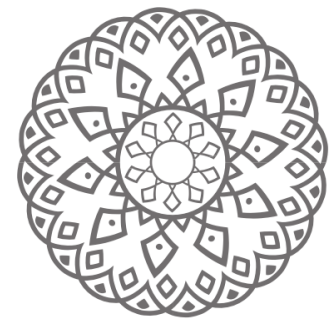

\title{
Revisiting The Role of WoMen as Witnesses in FiQh Justice
}

\author{
Dahwadin, Syaik Abdillah, Sasa Sunarsa, Muhamad Dani Somantri, \\ Enceng Iip Syaripudin, Hapsah Fauziah
}

\begin{abstract}
This paper discusses the role of women as witnesses in a court. This is one of the debatable issues in Islamic law considering the provision stating that the value of two women's testimony is equal to one man's testimony. Based on a more comprehensive discussion and by revisiting the Islamic resources on this issue, this paper concludes that the provision in the hadith, historically, regards heavily on women's capability and readiness to perform their duties as witnesses. It can be seen in the case of qadzaf where women can be witnesses for themselves (by stating four oaths in the name of Allah). Therefore, in the current development, women's role as witnesses needs to be reconsidered so that women can appear in the judiciary to play a role in supporting justice.
\end{abstract}

Keywords: Testament; Women; Fiqh 
Abstrak: Kesaksian pada intinya menuntut untuk menemukan dan membuktikan kebenaran terhadap masalah perdata dan pidana. Untuk menjadi saksi, ada beberapa kriteria khusus dalam memberikan kesaksian. Dalam Islam, hal-hal yang membutuhkan kesaksian seperti itu adalah pernikahan dan perceraian, hudud (perzinahan dan qadzaf). Mereka tidak mengizinkan perempuan menjadi saksi dalam masalah-masalah spesifik yang membutuhkan kesaksian. Salah satu daerah yang tidak memungkinkan perempuan untuk menyaksikan adalah wilayah hudud dan qisha. Hal yang menarik yang harus dicermati dalam ketentuan fikih adalah posisi wanita dalam memberikan kesaksian. Dalam Al-Qur'an tidak memungkinkan perempuan menjadi saksi di pengadilan, tetapi hanya dalam kasus perdata (transaksi keuangan), dan itupun bobot dua wanita sama dengan satu pria. Ketika kita merujuk pada makna teks, maka jelas siapa pun dia (wanita) dan kualifikasinya, bagaimanapun, tidak diperbolehkan untuk melayani sebagai saksi dalam kasus pidana. Meskipun secara historis telah terbukti banyak wanita cerdas, memiliki kedewasaan emosional, kredibilitas, dan kemampuan yang memenuhi syarat untuk tampil sebagai saksi dalam kasus-kasus, baik sipil maupun pidana. Dalam kajian fikih, yang populer, masalah kesaksian seorang wanita dinilai oleh sebagian orang sebagai salah satu perbedaan yang mensubordinasi perempuan. Sudah diketahui secara umum bahwa dalam Islam, antara pria dan wanita sama-sama bisa bersaksi. Kapasitas perempuan untuk menjadi saksi disebutkan dalam Al-Qur'an hanya dalam kasus perdata (yang bekenaan dengan hutang, jual beli, dan sebagainya). Jenis penelitian termakna dalam analisis ini menggunakan literatur penelitian (library research), yaitu untuk melihat bagaimana pandangan kesaksian perempuan dalam Islam melalui pendekatan analitik terhadap ketentuan dalam fikih keadilan yang kemudian ditinjau melalui studi ilmiah dengan berbagai corak diskusi dalam referensi lain yang mendukung analisis dalam tulisan ini.

Kata kunci: perjanjian; perempuan; fikih 


\section{Introduction}

Qur'an was not sent down in the middle of an empty desert, empty of culture, but it was sent down in the society with cultures and values. The Qur'an was revealed in a community where gender relations were dominated by men. Women were still regarded as sub-human (half human). The Quran uses the local language of the community where it was sent down. In fact, (to borrow a phrase Nasaruddin Umar) God borrowed the language or terms of such communities. Some of the terms used often considered to have a gender bias, in terms of vocabulary, grammar and categorization. One of the gender issues that often becomes a debate in academic discourse is the position of women as witnesses in court.

The position of women as witnesses in the judiciary has become a complicated and controversial issue up to now. The complication is not due to the teaching of the Quran as the primary sources of Islamic law, but because of the fanaticism in interpreting the Quran. The Quran is open to reinterpretation. The interpretation of the Quran involves not only hermeneutical issues but also ideological and political issues, which both are considered as part of the Westen influence. Moreover, an anti-Western sentiment like this is often mixed with bigotry against certain madhab or school of thoughts in Islamic law.

The Quran allows women to be a witness in courts, but only in civil cases (financial transactions). It is stipulated that two women are equal to one man (Q.S Al Baqarah, 2: 282). Referring to the text, it is obvious that women, with any qualification, are not allowed to serve as witnesses in criminal cases. Many women are intelligent, have emotional maturity, and credible to be witnesses in all cases, both civil and criminal cases.

In the case of Indonesia, many women have become judges in courts, general and religious courts. The struggle for the permissibility of women judges was started in the era of Wahid Hasyim when he has the Ministry of Religious Affairs. It was started with the establishment of a school for women judges. This shows that Muslims in Indonesia had never questioned the status of women as judges.

Thus, there is a gap between the discourse of fiqh with the dynamics of Muslims' lives, especially with regards to the position of women as 
witnesses in various legal cases. This paper aims at investigating the extent of issues in women's testimony and the possibility of rectifying the existing fiqh stipulation.

\section{Women's Testimony in Fiqh Discourse}

The discussion about testimony in classical fiqh books usually does not stand alone in one specific and complete discussion but is rather related to retrospective series of the case, or cases that needed testimony. This is very different from the contemporary fiqh books that usually discuss the issue of testimony in a single specific discussion.

The issue of women's testimony, by some, is often considered as the issue where women are subordinated. Refer to Quranic verses, men and women have equal capacity to testify. However, the capacity of women to be witnesses, as is mentioned in the Quran, is only in civil cases related to debts, buying and selling, and so on. The verse is as follows (Q.S. Al Baqarah,: 282):

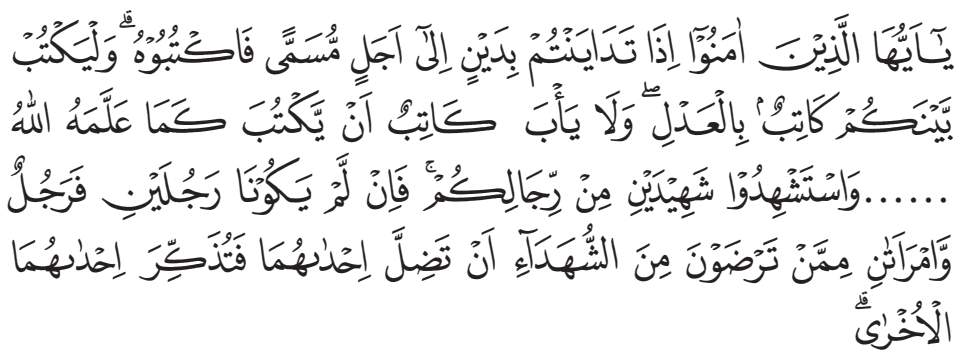

"O ye who believe, if you make transactions (finance) with no cash, within a certain period, you must keep listing it, and let the taker (the transaction) record to be honest. Do registrar was reluctant listing it sebagimana taught by God ....... Persaksikanlah (transaksi it) by two men among you. If there are not two men, then be witnessed one man and two women from those you love. If one between them forget or neglect, then one can be reminded again."

The verse explicitly states that women can be a witness. At the same time, this strengthens our belief that God has given women equal derajat with men. So, women can be included in a high-risk transaction and testimony as men. However, some Islamic jurists have not allowed women to be witnesses in some particular cases. Several cases where women cannot be witnesses are cases related to huddud and qishas. It is possible that this prohibition was because they considered unfamiliar 
and did not understand the issue. So, it has been impossible to ask women the problems they do not understand.

Another matter related to women's testimony is that the testimony of two women is equated with the testimony of one man. This seems to be a discrimination against women (Al Shafi, 1961: 1050106) by Islamic law (Syaltut, 1966: 249). Indeed, there are hadiths explaining the value of women's testimony. The reasons for this are because women are considered to have a lack or weak in intellectual and religion. The Quran mentions in the case of inheritance that the ratio of a son and daughter is 1:2. The following hadith explained the women's weak sense:

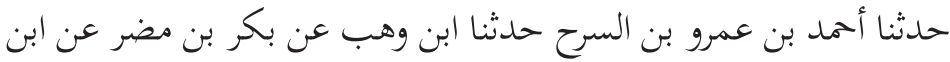

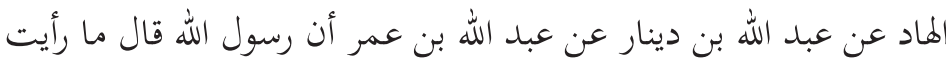

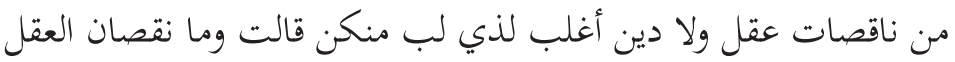

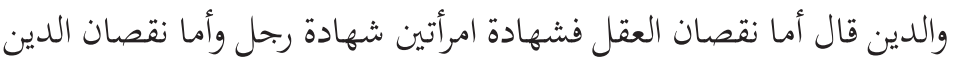

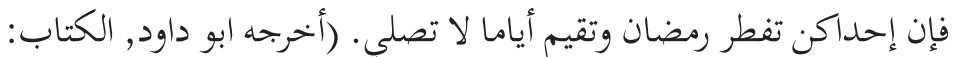

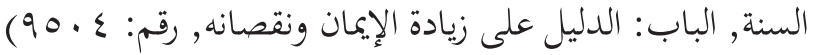

"Messenger of Allah, said:" I do not see the lack of reason and religion are more prominent but of you (women) ". Said one woman:" What is a lack of sense and religion "? Prophet said:" The lack of reasonable is (provision) the weight of the testimony of two women is equal to one man, while the lack of religion is that it means one of you have lunch in the month of Ramadan and leave the prayer for a few days."

$$
\begin{aligned}
& \text { حدثنا سعيد بن أبي مريم قال أخبرنا محمد بن جعفر قال أخبري زيد هو ابن }
\end{aligned}
$$

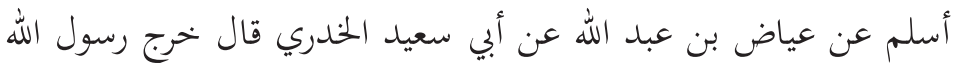

$$
\begin{aligned}
& \text { صلى الله عليه وسلم في أضحى أو فطر إلى المصلى فمر على النى النساء فقال }
\end{aligned}
$$

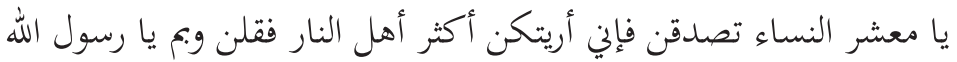

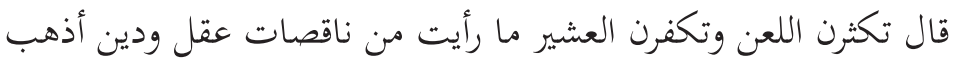

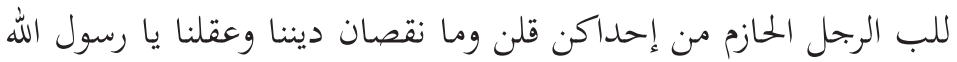

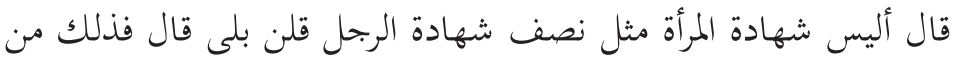

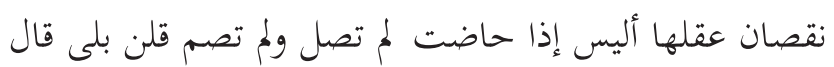

"The Prophet came out during the holidays Eid Al-Fitr and Eid al-Adha to the venue for the prayers, he passed by a group of women and said: "O our women, Believest you if I showed you that many of you later 
that an expert hell. Why is that yes, Apostle? Asked the woman. FAQ Apostle: "As many of you do anathema, kufr against the husband. I had not seen from the lack of reason and religion, which can eliminate the mind or heart of a man who firmly than any of you. "They said:" What lacks sense and our religion yes Apostle? "The Apostle," Is not the testimony of women equal to the testimony of a half men ? "." Yes, we admit it, "they answered. The Apostle said," then that is a shortage of mind. Is not when she had her period, she does not pray and do not fast?"

From those two hadiths, it can be understood that the difference in the weight of men's and women's testimony is related to their qualification. Women are considered to have a weak sense and religion. The information about these qualifications is further strengthened the weight difference between men and women's testimony in fiqh, as well as the provisions in the Quran. There is almost no discussion about the equality of men and women testimony in fiqh. In this regards, Sheikh Abu Syuja' states:

"That right, there are two kinds, the right of Allah, and the rights of the children of Adam. The rights of the children of Adam, there are three kinds: first, the rights therein are not accepted except by two male witnesses, namely on issues that had nothing to do with the treasure objects, and men are allowed to see it. Secondly, rights therein received two male witnesses, one male and two female witnesses, or one witness to the oath an accuser, namely on issues relating to the property. The three rights in which received the testimony of a man and two women, or four women for things that are not permissible for men to see it. As for the rights of Allah. Women were not allowed to be a witness (Abu Syuja, 68: 69).

Based on the above explanation from Abu Syuja', it can be seen that women have the capacity to be witnesses, but it is limited to civil cases or issues around properties. The explanation from Abu Syuja' reflects the general point of views in fiqh books with regards to women's testimony in courts.

\section{Testimony of Women in Marriage and Divorce}

Marriage is a sacred occasion. Given the importance of the event, there are requirements in a wedding ceremony. One of the compulsory conditions in a marriage is the presence of a witness. The majority of fiqh scholars agree that marriage is not valid in the absence of a witness. 
A hadith from 〈Aisha and Ibn〉 Abbas mentions this issue:

$$
\text { و و عن عائشة أن رسول الله صلى الله عليه وسلم قال: لا نكاح إلا بولي }
$$

"It is not considered a valid marriage (someone), except with a guardian and two witnesses were fair" (Sabiq, 1992: 13).

$$
\text { وأنفسهن بغنير بينة. . وعباس أن رسول الله صلى الله عليه وسلم قال: البغايا اللتى ينكحن }
$$

"Including people who are unlucky are the women who do the wedding himself without testimony" (al Authar, 125).

Nonetheless, some other scholars argue that a witness is not required in a marriage. Among these scholars are Thawr (Ibn Rushd; 50) Abd al-Rahman ibn Mahdi, Yazid ibn Harun, Ibn al-Mundhir, Ibn Umar and Ibn Zubair (Ibn Rushd; 50). According to Thawr, the witness is not a prerequisite in a marriage, whether it is to validate the marriage or to complete the ceremony. This was practised by Hasan ibn 'Ali. It was reported that he got married without witnesses, but he announced that (Ibn Rushd). Yazid ibn Harun argued that according to the Quran, witnesses are required in buying and selling transactions, not in a wedding ceremony. However, the rationalists or ashab alra'y insist that a marriage ceremony requires the presence of a witness (Sabiq: ). The Shia Imamate school asserts that the witnesses are not mandatory (Al Zuhaili; 194).

However, considering the benefit and wisdom of witness in marriage, which is to eliminate prejudice. It is crucial to consider the witness as it is something humane. As a social being, humans need acknowledgement from others when they conduct an Islamic based marriage ceremony. Fiqh talks about normative regulations in a marriage that should be met. The witness is considered mandatory. However, there are not many hadith that support the necessity of witness in marriage (Tirmid no. 1022).

The issue of witness also arises in a divorce. According to Sayid Sabiq, the majority of fiqh scholars agreed that the divorce is valid even without witnesses. This argument is based on the principle that a divorce is the prerogative right of husbands. They do not need witnesses 
to carry out their rights. This is because, at the time of the Prophet Muhammad and his companions, there was no indication of the need for witnesses in a divorce. As is mentioned in the hadith by the words of the Prophet (Tirmid no. 1022):

$$
\begin{aligned}
& \text { وعن بن عباس قال: أتى النبي رجل فقال يا رسول الله: سيدي زوجنى }
\end{aligned}
$$

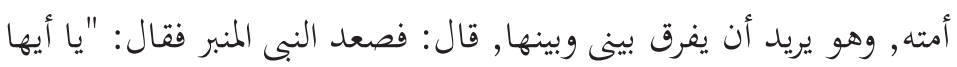

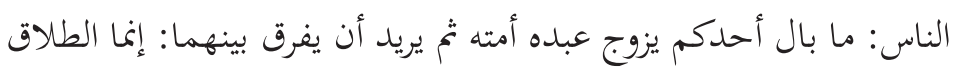

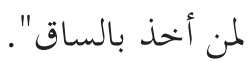

"From Ibn Abbas, he said:" There was one came to the Prophet and said: "O Messenger! Tuankumarries me with his slave girls, and Now he wants to meenceraikan me with him. "Thus the Apostle langusng up to the pulpit and said:" Hey man, how any of you who wed her male slave with a slave daughter, and then divorced her again? Indeed divorce is for people who hold the thigh, (i.e. screwed or have them) ".

The fragment in that hadith explains that talaq belongs to husbands. Thus, the involvement of others is unnecessary in its process. This argument is reinstated by Sayyid Sabiq, saying that the talaq is the right of a husband. God has made this right for the husband, and not for others. Sabiq based his opinion on the Quran, Sura al-Ahzab: 49:

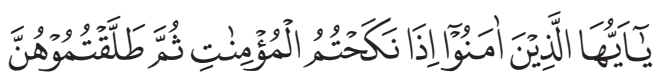

"Men who believe, if you married women - women who believe, then you divorce them ..”

However, Sayyid Saqiq did not give any further comment. He merely followed the general opinion on the meaning of the verse, that the marriage and divorce is the matter of husband, and not of someone else. This idea is unacceptable to Shiite Imamate scholars, stating that a witness is required for the validity of a divorce. This argument is based on the Quranic verse:

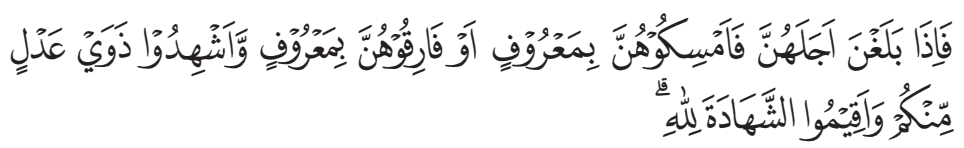

"When they were near the end of the iddah period, then rujukilah them well or deliver them in a good way, and get two witnesses just between you and let you establish the evidence fairly. (Q.S., 65: 2)" 
Al-Tabarsi argued this verse is evidence that the presence of a witness in talaq is a mandatory command. According to the Shiite Imamate, this was confirmed in the report by Abl Albait (Sabiq: 220). Among the companions who supported the need for witness in a divorce were: Ali ibn Abi Talib and Imran Ibn Husain. Meanwhile, among the tabi'in were Muhammad al-Baqir, Ja'far al-Sadiq, 'Ata', Ibn Jurayj and Ibn Sirin. In the book of Al-Kalam by Jawahir, as is cited by Sayyid Sabiq, mentioned that a man asked Ali ibn Abi Talib about his divorce. Then, Ali ibn Abi Talib asked this guy whether his divorce was witnessed by two witnesses as is in command of Allah and His Messenger. The man answered "no". After that, Ali ordered him to go back to his wife and said that the talaq was invalid (Sabiq: 220).

From the above explanation about the witness, it can be understood that the requirement of witnesses in a divorce has a strong foundation. Regardless of the differences in the above arguments, a witness in a divorce benefits women. With the proposition that a divorce is a husband right, the position of a woman becomes weak. With the compulsory witness in a divorce, women can defend their rights. Women can ask other people to be a witness and put pressure on their husband. Therefore, witness becomes a helpful means for women to strengthen their position, vis-à-vis their husbands in a divorce.

The next question, after that, is about who has the right to testify. Are both male and female equally permissible to become a witness? Fiqh requires certain conditions to be a witness. One of the controversial issues in witness is regarding dzukurah, which means that a witness should be male. In other words, a woman is not allowed to be a witness, both in marriage and divorce. This argument posed by scholars from Shafi'ites and Hanabila. They cited a hadith that forbid women to be witnesses in hudud cases, marriage, and divorce (Sabiq: 51). Scholars from Hanafiya, on the other hand, do not require dzukurah. They allow one man or two women to be witnesses in a marriage contract or divorce. In this regards, they similarize the marriage contract to buying and selling, as stated in the Quran (Sabiq: 51). A similar point of view was also stated by Ishaq and Ahmad, which agreed to the role of a man or two women as witnesses in a marriage ceremony.

There are two problems that underlie the controversy of women becoming witnesses. First, the narrowness of the discourse that allows 
women to be witnesses in marriage and divorce. Even though women can be witnesses in these two cases, the testimony of two women is equalized to the testimony of one man. In addressing this issue, it is important to look at its legal foundation. First, the prohibition of women to become witnesses in marriage and divorce is not mentioned in the Quran. None of the Quranic verses states that women are not allowed to testify. The basic foundation of the argument is a hadith narrated by al-Zuhri, which has been widely quoted by fiqh books. This hadith stated that women might not testify in hudud cases, marriage, and divorce (Tirmidhi, 1022). Hadith of al-Zuhri was published in the book "Al-Kharraj", and "Talhis al-Kabir" with the full narration as follows:

$$
\begin{aligned}
& \text { مضت السنة من رسول الله صلى الله عليه وسلم والخليفتين من بعده أن لا }
\end{aligned}
$$

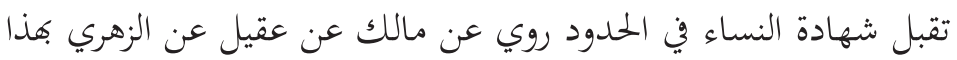

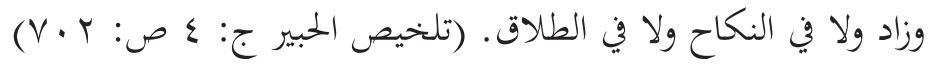

Never valid (but already passed) the Sunnah of the Prophet, and two caliphs afterwards that the testimony of women is not acceptable in hudud, and narrated by Malik of Uqail of Zuhri said, adding that the testimony of women was also not accepted in marriage and divorce".

The actual narration in the above hadith is unclear. The statement above is merely a summary of the scholars' discussion about the hadith. The quote above is more about the story of tabiin about the Sunna that never applied at the time of the Prophet and the first two Chalipates. Therefore, the statement is not a hadith, but only sira or a story from the past, which was the period of the Prophet. Imam al-Malik saw that this hadith (if assumed to be the case) is not authentic. However, Imam al-Malik did not explain the fault of this hadith (Al habir,: 207). Thus, the extent to which the expression is identified as a hadith to prohibit women from becoming witnesses in divorce, marriage and hudud is feasible. Second, historically, the prohibition of women to testify becomes possible considering that women at that time were considered incapable.

With those two reasons, the questions after that are why are women prohibited from becoming witnesses? And if they can become witnesses, why do their value only half of a man? This paper argues that the prohibition of women to become witnesses has not been based 
on a firm and strong proposition. This is because women can be as intelligent as men or can be far more intelligent than men. This means that women are intellectually and mentally ready to act as witnesses.

\section{The Testimony of Women in the Hudud Cases}

Etymologically, hudud is the plural form of had, which means a band or limit (Madhuur, 1990: 1400). According to Sayyid Sabiq, etymologically, hudud is the separation of two matters or a matter that distinguish one from another. Hudud also means prevention (Sabiq: 302). Hudud can mean a form of punishment that is intended to prevent the perpetrators from repeating their actions, which can be resulted in more punishment. In the legal term, hudud means a punishment prescribed for humans who commit forbidden actions (Mandhuur, 1990: 1400). According to Sayyid Sabiq, the provision of this law is directly determined by the Law Maker, i.e. Allah, for the sake of public goods and to maintain public order, as the main purpose of the religion of Allah. Because the law comes from God, then, there should never be an abortion (isqath), either from individuals or groups of people (Sabiq: 302).

Actions subjected to hudud, according to Imam Abu Syuja, are adultery, qadhf (accusing people to commit adultery), drinking alcohol liquor, theft (sariqa), muggings on the street (qitha' al-tariq), killing animals, rebelling against the legitimate government (bughat), and abandoning prayers (Abu Syuja, 56: 58). Meanwhile, according to Ahmad Abdullah al-Narim, there are six offenses that lead to huduud such as theft (sariqa), haraba, adultery, accusing someone committing adultery), drunk (sakr), and abandoning Islam (ridda). However, alNa'im restricts the implementation of hudud only for the violations that are specifically mentioned in the Quran, such as sariqa (Q.S. 5: 38), Haraba (Q.S. 5: 33), adultery (Q.S. , 24: 2), and qadhf, while the other two offenses such as sakr (al Naim, 2001: 206-207) and riddah (al Naim, 2001: 206-207) are still disputable due to the uncertain penalties for these types of violation.

In various cases, women's testimony is considered invalid. The following discussion will explain the invalidity of women's testimony from the theological and sociological perspectives. However, the 
discussion will focus only on two cases that involve women, which are adultery and qadhf.

\section{Adultery}

As is explained earlier, adultery is one of the actions that cause a person to be sentenced by hudud. All the religions of the world, without exception, regard adultery as licentious acts. In Islam, the perpetrators are subject to severe penalties. Why is that? First, adultery is considered an unlawful act against the law of God. Second, the moral ethics of adultery is a reflection of irresponsibility. Third, adultery leads to certain losses, especially for women, because there will be no legal consequences for both parties in the relationship. For example, it will be hard for a woman to demand the responsibility of a man to take care of a child that born outside wedlock.

As for its definition, according to Ibn Rushd, adultery is intercourse performed outside a legitimate marriage. This definition is generally accepted by most Islamic scholars (Ibn Ruushd: 324). Muhammad Ibrahim Al-Badjuri, in his book Al-Badjuri khosyiyah, defines adultery as inserting male genitalia, who is mukallaf (adult subject to Islamic law) into female genitalia (Al Bajuri: 229). This definition excludes adultery committed by children (underage) and insane people. In fiqh, those who are not considered mukallaf cannot be punished for adultery even though they commit it.

In the fiqh discourse, people who commit adultery can be categorized into two: muhsan and ghair muhsan. Muhsan is adultery committed by married people, while ghair muhsan is adultery committed by unmarried people. Muhsan adulterers are punished by stoning to death Sabiq: 346). Whereas, ghair muhsan adulterers are punished with a hundred lashes (jild) and exilement (Sabiq: 345-346). A year exilement is equal to the travel period limit that enables qashar in prayers (Sabiq: 345-346). As is mentioned above, both types of adulterers are punished with different level of punishment. However, to pass sentence, there are some compulsory requirements that should be met. One of them is the testimony from four witnesses, which will be discussed further in this paper. 


\section{Qadzaf}

Another form of violation that is punishable by hudud and requires a testimony is qadzf. Forms other acts punishable hudud and require their testimony is qadzaf. Literally meaning, qadzf is throwing stones or be together with others (Sabiq: 372) or posing accusation (Abu Jaid, 1988: 297). The first meaning refers to God's word:

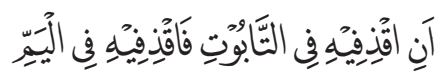

"Put it (Moses) into the crate, then throw it into the river (Nile) ... (Q.S. 20: 39).

While the second meaning is in accordance with the Quran:

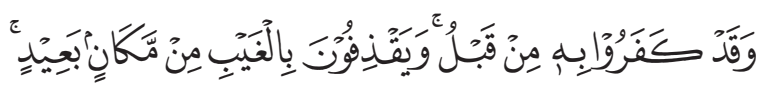

"And indeed they have denied God before it, and they guess the unseen from a distant place (Q.S. Saba, 34: 53)."

In general, the case of qadzf can involve anyone, regardless of their gender. However, in the books of figh, the accusation is inflicted to woman. This is because, in the Quran, the word used in the discussion of qadzf is a mubsanat or female adulterer. However, even though in fiqh, the charges of adultery is addressed to women, the charges can actually be for men and women.

Thus, the definition of qadzaf etymologically is taken from the Quran. In Islamic legal terminology, qadzf means false accusation of adultery (Sabiq: 372). Three factors should exist in the qadzaf cases: 1) a person who commits qadzf; 2) the accused person; 3) matters used in the accusation. These three factors should meet several conditions. For the perpetrator, he/ she should be intelligent, mature, and without coercion. As for the accused person, he/she has to be intelligent, mature; a Muslim has never committed adultery and a free person (not a slave). Maqdzuf bih, on the other hand, should be clear, committed without further thought from the perpetrator, use a pejorative language or satire. In this regards, Imam al-Malik argued that those unexplicit expressions are equal to explicit statements (Sabiq: 373 - 376).

As is explained earlier, hudud is for those who commit apostasy, drinking liquor, haraba, and so on. However, two cases that directly related to women are adultery and qadzf. Basically, both cases 
cannot proceed without clear evidence and witnesses. In this case, this paper proposes a mechanism for testimony related to cases involving women.

The accusation of adultery undermines the credibility, dignity and honor of a person, whether it is a male or female, and his/her family. This also impacts the life of the accused person. Therefore, Islam is very strict in dealing with the accusation of adultery. In fiqh, there are many requirements that should be met in accusing others of committing fornication. Sayyid Sabiq argued that to be accepted; the fornication should be witnessed by four male witnesses, as is mentioned in the Quran:

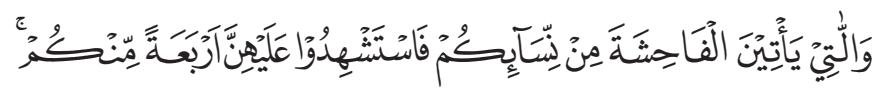

"And against women among you who act fahisyah (i.e. adultery), let four witnesses from among you watch (Q.S.: an Nisa, 4: 15)."

Based on this verse, in the adultery case, there should be four men witnessing the action. The number is very strict. The accusation of adultery is unacceptable with less than four men witnesses. As is mentioned in the Quran:

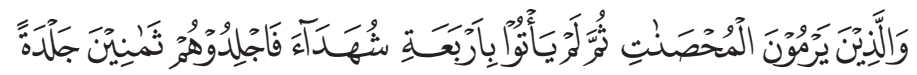

"And those who accuse a woman committing adultery (muhshanat), and they do not come with four witnesses, whip them with eighty lashes..."

Second, these witnesses must be the people who are already mature (baligh), and not children. This is based on the following verses:

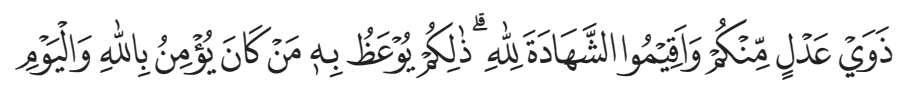

"Witness it (a transaction) by two males among you. If two men are not available, then one man or two women from the witnesses."

Based on this verse, a witness must be an adult male. The testimony of a child is unacceptable because a child is not categorized as rijal (adult male). Third, the witness must be an intelligent person. An insane person whose mind is unhealthy is unacceptable to be a witness. Fourth, the witness should be just. This is based on the Quran: 


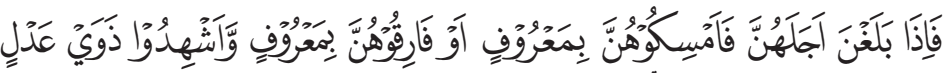

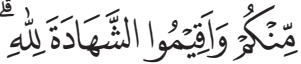

"When they were near the end idahnya, then rujukilah them well or deliver them in a good way, and get two witnesses just between you and let you establish the evidence fairly. (Q.S., Al Thalaq, 65:2)"

Fifth, the witness should be a Muslim, whether the testimony is intended for Muslim of non-Muslim (Sabiq: 354). Sixth, the witness should clearly see the actions committed by the perpetrators. In this case, the witness watches the act of sexual intercourse of the perpetrators (Sabiq: 354). Seventh, the testimony is mentioned in a clear and direct language, and not with kinayah or sindiran. Eight, the should be no differences or disputes among witnesses regarding the place and time of the action. Shafi, Zaydiyyah and Dhahir scholars do not recognize this term (Sabiq: 355). Ninth, the witness should be male or dzukurah. In this case, women's testimony is unacceptable. Tenth, the testimony is not for very past case ('adam al-taqaadum) (Sabiq: 355).

From those requirements in the adultery cases, it can be concluded that Islamic law requires complex terms and conditions to prove someone committing adultery. If those conditions are met, then the adulterer is punished by stoning.

The testimony in qadzaf case, on the other hand, is mentioned in the Quran as follows:

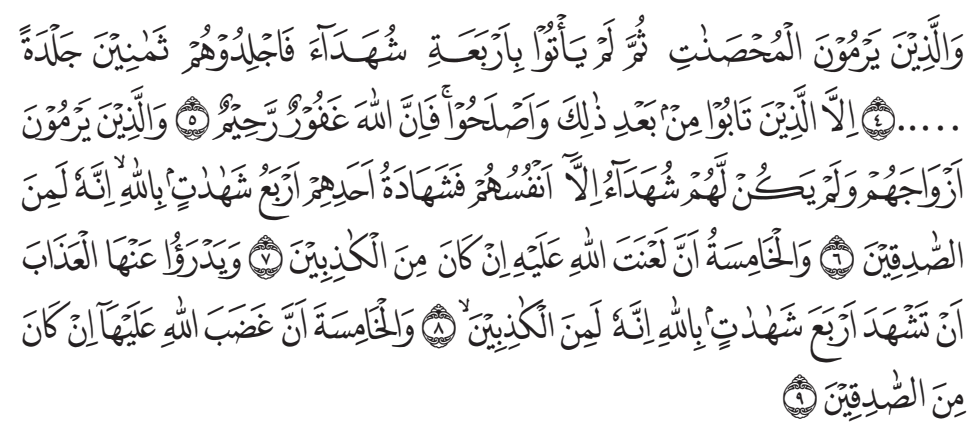

"And those who accuse women muhshanat (Adultery), and they do not produce four witnesses, then cambuklah them eighty lashes ... .. And those who accuse their wives (adultery), but they have no witnesses except themselves, then the testimony of one of them be four times swear by God, sesungghunya he was among those who correctly. 
And(Oath) the fifth, invoking the curse of Allah on when it includes people - people lie. His wife was avoided punishment by oath four times in the name of Allah; the husband was among those who lie (Q.S. al Nur: 24: 4-9)".

This verse suggests that to prove someone committing qadzaf, there should be for male witnesses. If not, the pengadu receives eighty lashes. However, if the pengadu swear four times by the name of God, then the testimony is accepted. At the same time, if the woman who is accused of committing adultery swears for a time by the name of Allah, she will be freed from the punishment.

\section{Testimony of Women}

In the cases discussed above, women's testimony is unacceptable. Women can defend themselves in the case of adultery accusation by the oath in the name of Allah. The question, then, is the testimony similar to the oath for women? Is women can be a witness to herself and only for herself, not for others?

It appears that there has been a strong patriarchal bias in the interpretation of the Quran and Hadith related to the role of a woman as a witness. In the above cases, it can be seen that women are the subordinate of men. Women are in the second class compared to men. The case becomes more complicated when the adulterer is a woman, and the witnesses are only women. Therefore, there is a need to reconsider the limited role of women in the case of hudud in Islamic law.

As is noted earlier, the prohibition of women as witnesses in marriage, divorce, and hudud is not in the Quran but in the hadith, in which its authenticity level is questionable. This is because the hadith is not directly the saying of the Prophet. The hadith is only a story by Zuhri, who is a tabi'in, about what happened in the time of the Prophet. Al-Malik did not consider the hadith authentic (al Habir: 207). With this explanation, there is a need to reconsider women role as witnesses as is in the books of figh and start including women as witnesses in the case of hudud.

The question, after that, are women weak in terms of intelligence and religion? If so, it becomes to make sense when women's testimony 
weighs only half of men's. However, the stipulation of the women's testimony weigh is not because women are weak, but based on the prescription in the Quran. However, fiqh scholars tend to base their argument on the weakness of women in reason and religion.

The weigh of women testimony in fiqh is based on the Quran, Sura Al-Baqarah: 282. Some scholars have used this verse to base their argument stating that women are weak in their intelligence and religion. The verse explicitly states that the testimony of a man is proportional to the testimony of two women. However, it is important to note that this provision is for matters related to financial contracts, not for other things. The irony is that some of the fiqh scholars generalized this provision for some other issues. In the past, women were considered weak due to the social system that regarded women as subhuman (half man). This becomes to make sense if two women's testimony is equalized to one man's. Thus, women are not weak by nature.

In some cases, women are allowed to act as a witness to themselves. The Quran allows women to act as witnesses as men. One of the cases involving women as witnesses in the time of the Prophet was the case of rada'a (breastfeeding). The explanation is available in the hadith of Tirmidhi as follows (al-Tirmidhi no. 1071):

$$
\begin{aligned}
& \text { حدثنا علي بن حجر حدثنا إسمعيل بن إبراهيم عن أيوب عن عبد الله }
\end{aligned}
$$

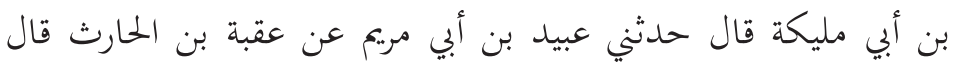

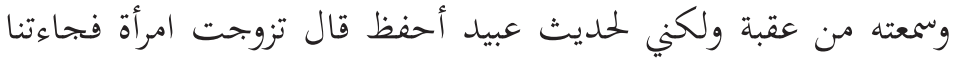

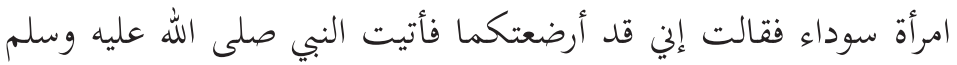

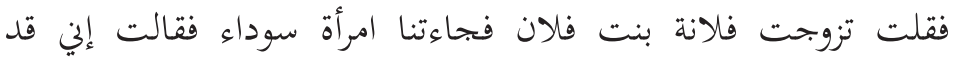

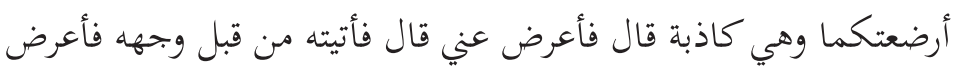

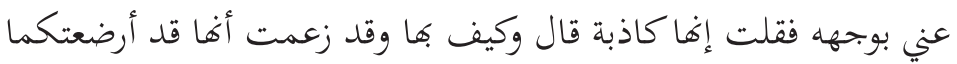

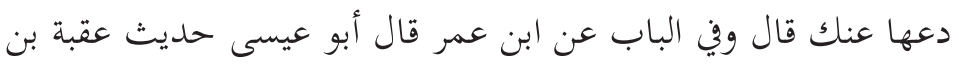

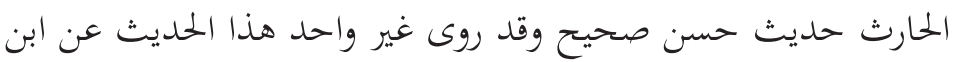

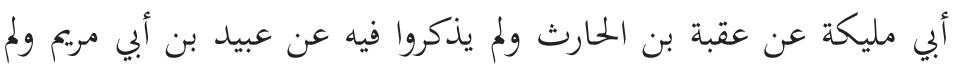

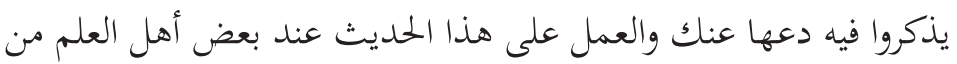




$$
\begin{aligned}
& \text { أصحاب النبي صلى الله عليه وسلم وغيرهم أجازوا شهادة المرأة الواحدة }
\end{aligned}
$$

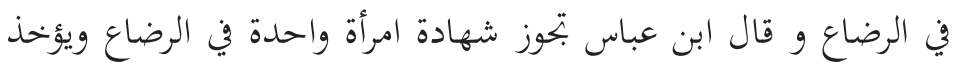

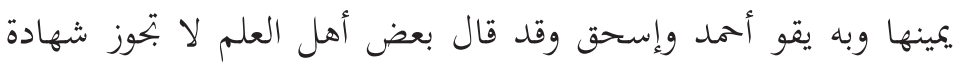

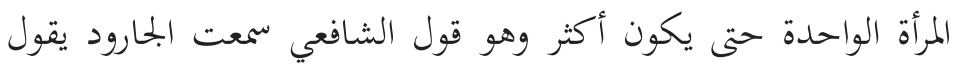

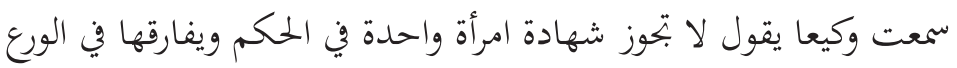

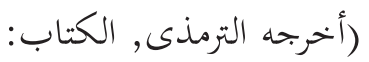

The history reveals that the testimony of a woman was permitted by the Prophet, although there are some differences. In those cases, women can act as a witness for themselves. This means that women were seen to be ready, and their capability was admitted. If so, why do not we consider women's testimony at the present day? When are women considered to have the capability as witnesses?

The contemporary Muslim scholars, such as Muhammad Abduh, state that the above verse does not imply women's inferiority. The provision of 1:2 of men and women's testimony was for a financial transaction where women's experience in business was considered less than men. Abduh also notes that the verse of Al-Baqara: 28 has not meant to be followed as an obligation. The verse is only a suggestion. If the Quran indeed sets a 2: 1 to be strictly followed, then there should be a similar expression on other verses on testimony issues (Ridha,: 124).

This shows that Muhammad Abduh also saw that the provision regarding women's testimony follows the level of women's readiness. Thus, this paper argues that the rationalization of the stipulation in the sacred text is necessary. According to Salbiah Ahmad, a woman's testimony in hudud and qisas happened in the history of Islam. One case was the testimony of a wife named Naila for the murder of her husband, Umar. Based on her testimony, Ali Abu al-Din Lulu punished the killer by hudud. This case shows that a woman's testimony is sufficient in legal decision making. With historical events and the obscurity of the argument that prohibit women from witnesses, Salbiah Ahmad argues that anyone is capable of becoming a witness (Ahmad,: 43). 


\section{Conclusion}

To conclude, in general, the issue of women's testimony is regarded as subordination against women. Women are not allowed to be witnesses in some particular cases such as hudud and qisas. Another issue is that a woman testimony is only counted as half of a man. This means that one man is equal to two women. The classical figh scholars tended to prohibit women from becoming witnesses in those two cases. They based their argument on the provisions in the Quran and hadith about the case. This has resulted in the narrow interpretation of both resources. Contemporary fiqh scholars revisit the stipulation in the classical fiqh by considering historical spectacles. This allows changes in the provisions by considering the capability to perform their duties.

From the analysis of the verses and hadith on the women testimony issue, this paper concludes that the provision in the hadith, historically, regards heavily on women's capability and readiness to perform their duties as witnesses. It can be seen in the case of qadzaf where women can be witnesses for themselves (by stating four oaths in the name of Allah). In the current development, women's role as witnesses needs to be reconsidered. Thus, women can appear in the judiciary to play a role in creating justice, especially in sexual harassment related cases.

\section{Reference}

Abu jaib, Sardi Al-Qamus al-Fiqhi, (Damascus: Dar al-Fikr, 1988).

Ahmad, Salbiah, Evidence of Woman (as Witnesses), Diyat And Apostasy, the Rose Ismail (ed.), Hudud in Malaysia The Issues at Stake, SIS.

Al-Bajuri, Ibrahim al-Bajuri Hassiyat, vol 2.

Al-Narim, Abdullah Muhammad, Deconstruction Shariah, trans. Suaedy and Amiruddin Ahmad al-Rany, (Yogyakarta: LKIS, 2001).

Al-Shafiri, al-Umm, (Cairo: Maktabat al-Kulliyat al-Azhariyyah, 1961

Al-Zuhaili, Wahbah, Fiqh al-Islam wa Adillatuhu, vol. 7.

Majah, Ibn, Sunan, (Riyadh: Maktabat al-tarbiyat al->Arabiyah, Vol 1).

Mandhur, Ibn, Lisan al->Arab, (Beirut: 1990, Vol 3).

Rashid Rida, Muhammad, Tafsir Al-Manar, (Beirut: Dar al-Fikr, vol. III).

Rushd, Ibn, Bidayat al-Mujtahid, Dar al-Fikr, nd, vol. 2.

Sabiq, Sayyid, Fiq al-Sunnah, (Beirut: Dar al-Fikr, 1992, Vol. 2) 
80 - Dahwadin

Syaltut, Mahmud al-Islam «Aqeedah wa Shariah, Dar al-Qalam, 1966.

Syuja «, Abu, Taqrib, Indonesia, Dar al-life, tt

Umar, Nasaruddin, interpretation of Scripture Gender Perspective: Perspective of the Quran, (Seminar Papers Pre NU in Garut, 17 November 1999.

Organizers Foundation and Pentafsir Translations of the Quran, Quran and Terjemahnya, (Jakarta: 1971).

Dahwadin, Syaik Abdillah, Sasa Sunarsa, Muhamad Dani Somantri, Enceng Iip Syaripudin, Hapsah Fauziah, Islamic University of Al Musaddadiyah Garut.

E-mail: dahwadin@stai-musaddadiyah.ac.id 